\title{
Towards Transit-Oriented Development for Sustainable Urban Mobility: Insights from a Central European City
}

\begin{abstract}
Sustainable Development Goals require holistic actions, including activity at the intersection of urban planning and environmental engineering. Turning our cities towards transit-oriented development might help in reducing pollutant emissions caused by individual transportation modes that rely on crude oil. This research presents how the use of geospatial network analysis can support local decision makers in the evaluation of potential public transport accessibility by citizens in the case of a Central European city - Wrocław (Poland). The obtained results indicate differentiation in access to railway stations and stops, which results from pedestrian path networks and the number of entrances to railway stations. The visualization of serve area shows which parts of the city are excluded from comfortable access to public transport and in that way highlight where future actions should be taken.
\end{abstract}

Keywords: sustainable transportation, public transport, urban rail, geospatial network analysis, transit-oriented development

Received: 29 January 2021; accepted: 3 March 2021

(C) 2021 Author. This is an open access publication, which can be used, distributed and reproduced in any medium according to the Creative Commons CC-BY 4.0 License.

1 Wrocław University of Environmental and Life Sciences, Student Scientific Organization of Spatial Management PUZZLE, Wrocław, Poland, email: max.lesniewski11@gmail.com

2 Wrocław University of Environmental and Life Sciences, Institute of Spatial Management, Wrocław, Poland, email: malgorzata.swiader@upwr.edu.pl, ORCID ID: https://orcid.org/0000-0003-3398-4985

3 Wrocław University of Environmental and Life Sciences, Institute of Spatial Management, Wrocław, Poland, email: iwona.kaczmarek@upwr.edu.pl, ORCID ID: https://orcid.org/0000-0002-0738-484X

4 University of the Basque Country, Department of Financial Economy II, Vitoria-Gasteiz, Spain, email: david.garciac@ehu.eus, ORCID ID: https://orcid.org/0000-0003-4819-7116

5 Wrocław University of Environmental and Life Sciences, Department of Mathematics, Wrocław, Poland, email: joanna.kaminska@upwr.edu.pl, ORCID ID: https://orcid.org/0000-0002-0157-516X

6 Wrocław University of Environmental and Life Sciences, Institute of Economics Sciences, Wrocław, Poland, email: tomasz.pilawka@upwr.edu.pl, ORCID ID: https://orcid.org/0000-0003-3368-1941

7 Wrocław University of Environmental and Life Sciences, Institute of Spatial Management, Wrocław, Poland, email: jan.kazak@upwr.edu.pl, ORCID ID: https://orcid.org/0000-0002-1864-9954 


\section{Introduction}

Current global challenges connected with climate change force decision makers at both the international and local level to strengthen activities aimed at adapting the built environment to natural hazards [1]. In order to set a pathway for these actions, on the $25^{\text {th }}$ of September 2015 over 150 countries agreed to new 17 ambitious Sustainable Development Goals (SDGs) within the Transforming our World: the 2030 Agenda for Sustainable Development [2]. SDGs focus on topics which are widely studied by researchers from different domains, such as end of inequality and poverty $[3,4]$, take action on climate change and prevent the degradation of the environment [5-9], ensure access to affordable and clean energy [10-12], promote health and face ageing society challenges [13-15], build strong institutions and partnerships $[16,17]$, etc. The broad context of these goals shows that countries and regions should not only focus on one selected issue, but implement integrated actions in order to improve the quality of life [18]. However, taking into account the complexity of socio-environmental systems connected with the fact that the change of one element cause effects in many other elements, as well as the modifications to many elements that have to be made to reach one goal, the achievement of a few SDGs might be connected with specific sectors of the global economy [19].

In the same year that the SDGs were announced, the Partnership on Sustainable, Low Carbon Transport released its report on "Contribution of Transport Commitments to Global Goals on Sustainable Development". According to this report, sustainable transport may enable all 17 of the SDGs to be reached. One of the modes of sustainable transport mentioned was rail transport [20]. This domain was also the focus of specialists in the following years. On the $14^{\text {th }}$ of March 2017, during the Centre for Regional Development of the United Nations forum, one of the pivotal sectors discussed as influencing SDGs in transportation was the rail system. The background paper titled "Railways as the Backbone of Environmentally Sustainable Transport and their Contribution to the Sustainable Development Goals (SDGs)" presents arguments from the participants of that meeting. The main features highlighted were that sustainable transport is safe, affordable, accessible, efficient, resilient and minimizes carbon and other emissions and environmental impacts. The development of sustainable transport provides opportunities to save hundreds of thousands of lives every year through improved road safety and reduced air pollution, and reducing carbon emissions by 7 gigatonnes [21]. In terms of urban mobility, it was stated that rail can potentially very well serve the great volumes of traffic centered in the metropolitan cities, coming and going from the suburbs and the outskirts of the city. Moreover, the car congestion of the roadways entering the city is a competitive advantage for rail. In many cases, high density urban development is connected to the railway system which gives an opportunity for local railway system development. The latest “The Sustainable Development Goals Report 2019" set exact benchmarks which support decision makers at the local level to guide them how 
to make cities and human settlements inclusive, safe, resilient and sustainable. According to that report, convenient access from a housing area to railway infrastructure is $1000 \mathrm{~m}$ [22]. Based on this assumption, cities can assess their spatio-functional structure and analyze scenarios for future development in order to maximize the number of potential users to develop local rail systems.

Accessibility to public transport modes is not only a point of interest at the political level but also at the academic considerations supporting local sustainable development [23-25]. The assessment of public transport accessibility refers to a few basic elements which have to be taken into account as assumptions in order to define accessibility zones. However, at first it should be highlighted that there are no universal values describing acceptable walking distances to public transport [26]. Milakis and van Bee connected acceptable travel time with, among others, biological abilities and constraints, cultural and social norms, perceptions, feelings and experiences, land use system, labor and housing markets, destination-related and travel related utility [27]. In the case of Munich, Sarker observed that pedestrians on average walked longer for suburban trains and subways rather than take a bus and tram. Moreover, acceptable walking distance varied within the analyzed area. Users living in low density areas walked comparatively longer than respondents living in the central business district [28]. Therefore, accessibility assessment in each case should be limited to the area representing similar spatial and socio-economic conditions. A variety of these conditions were noticed for instance in English conditions, where the average walk to a railway station is $740 \mathrm{~m}$ in London and 1,010 m elsewhere [29]. That corresponds with results from Beijing, where according to the opinion of $85 \%$ of pedestrians, acceptable limits were within about $1 \mathrm{~km}$ and the acceptable time for walking was about 12 minutes [30]. It is important to highlight that the walking accessibility zone (sometimes called the walkable catchment) should not be considered as the radius from destination point, but should take into account the existing network that enables physical access by the user. Such an approach was presented on the case of Greater Dublin, where $1 \mathrm{~km}$ also defines the accessibility zone [31]. The $1 \mathrm{~km}$ for train accessibility is considered as a benchmark value for transit-oriented developments (TOD) [32] which help to make cities more environmentally friendly [33].

Despite the well-known standards of accessibility to public transport, it does not imply that all cities undertake local studies to assess their situation. As a result, some urban development decisions are not based on the knowledge of possible implications but rather on the willingness to implement some investments, as has been presented in Poland for instance [34]. As a result, the existence of urban development documents does not guarantee that their realization would lead to more sustainable urban structures $[35,36]$. Based on the literature review, the research question that arises is how to analyze future development scenarios to maximize the number of potential users for the local development of railway systems. Poland, as the largest member state in the European Union to have been under Soviet influence 
prior to the 1990's, is one of the key countries which has to enforce its activity in order to meet SDGs and improve its environmental performance. Therefore, the aim of this study is to analyze rail accessibility in a regional city that does not have an existing urban train to define actions which should be implemented to enable the development of such a system.

\section{Materials and Methods}

The case study for this research was Wrocław, a regional city in south-western Poland. It is the capital of the Lower Silesia region, with a surface of $293 \mathrm{~km}^{2}$ [37]. Wrocław is the fourth largest city in Poland, with the number of registered inhabitants of 640,648 . The total number of citizens is higher due to the number of students (approx. 114,825) as well as domestic and foreign migrants [38]. The urban structure of Wrocław is influenced by highly complex hydrological network of five rivers, which is assumed as one of the most complex hydrological systems in European cities [39]. It results in over 100 bridges in the city, which in turn influence the road system and congestion of vehicles travelling in the city. According to the Provincial Environment Protection Inspectorate, road traffic in Wrocław is responsible for $56 \%$ of $\mathrm{NO}_{2}$ emissions, $44 \%$ of $\mathrm{CO}$ emissions and $16 \%$ of PM2.5 particulate emissions [40] which testifies to the importance of the implementation of sustainable urban transportation.

The potential service area for railway stations in Wrocław were determined using network analysis tools. The analyzes were carried out in the ArcGIS (version 10.6) ESRI environment using the available algorithms implemented in the Network Analyst extension. One of the functionalities of this tool is the ability to specify the so-called service areas defined as areas accessible from a specific base point in specified parameters, i.e. travel time or distance. These areas are determined using the Djikstra algorithm, allowing the search for the shortest path in a graph with non-negative edge weights, connecting the starting node $p$ with the end node $k$. In the algorithm for creating a service area, the shortest roads in the network are determined from the initial point given specific costs. Based on the generated edges, triangulated irregular network (TIN) data is then created. TIN vertices take weights from the network (it can be e.g. distance from the starting point in the network).

Designation of service areas was carried out taking into account pedestrian traffic. The assessment of the availability of railway stations was carried out for service areas limited to the maximum acceptable travel time. In the case of acceptable walking distance, $1 \mathrm{~km}$ was used [22]. Based on the fact that the minimum energy cost required to walk a given distance occurs at a speed of approximately $5 \mathrm{~km} / \mathrm{h}$ (also the preferred walking speed of normal-weight adult) [41], the acceptable time of travel was around $12 \mathrm{~min}$. 
For the purposes of the analysis, mostly open data was used, i.e. OSM (Open Street Map) data and open data provided from city of Wrocław. Entrances to railway stations were mapped based on the field inventory with the use of Collector for ArcGIS (Tab. 1). Each entrance to the railway station was assigned as the destination point in the accessibility of railway station, therefore, a few separate accessibility analyses for one station could be performed.

Table 1. Data sources

\begin{tabular}{|c|l|l|l|l||}
\hline No. & \multicolumn{1}{|c|}{ Data } & \multicolumn{1}{|c|}{ Source } & Link to source & \multicolumn{1}{|c||}{ Format } \\
\hline \hline 1. & Streets ${ }^{1}$ & Open Data Wrocław & https://www.wroclaw.pl/open-data/ & SHP \\
\hline 2. & $\begin{array}{l}\text { Boundaries of } \\
\text { urban districts }\end{array}$ & $\begin{array}{l}\text { Spatial Information } \\
\text { System of Wrocław }\end{array}$ & https://www.geoportal.wroclaw.pl/ & SHP \\
\hline 3. & Buildings & Open Street Map & https://www.geofabrik.de/ & SHP \\
\hline 4. & $\begin{array}{l}\text { Entrances to } \\
\text { railway stations }\end{array}$ & Field inventory & Not applicable & $\begin{array}{l}\text { Transformed } \\
\text { to SHP }\end{array}$ \\
\hline \hline
\end{tabular}

${ }^{1}$ Including all types of paths accessible for pedestrians.

Accessible open data did not allow us to perform analyses directly. Initial verification of the topology of the network resulted in over 5000 non-continuous errors. After improvements, we created a topologically correct road network. It was assumed that the network should include public main, collective and local roads, road and path sections excluded from car traffic. The network also included paved sections of tram tracks and bicycle paths which are usually associated with possibility of pedestrian mobility. Appropriate attributes are also defined for the edge of the network. One of them is the cost of traffic along a given segment of the network, the value of which increases with the length of the edge. For the purposes of analysis, the cost of the segment was expressed by the time necessary to cover a given section of the network, calculated as the quotient of the segment length and the permissible speed of movement (expressed in minutes).

\section{Results}

Based on the field inventory of 24 railway stations and stops in Wrocław, and the methodological approach as described above, areas within the distance of $1 \mathrm{~km}$ from each entrance of railway stations and stops was achieved. Spatial distribution of these areas is presented in Figure 1. 


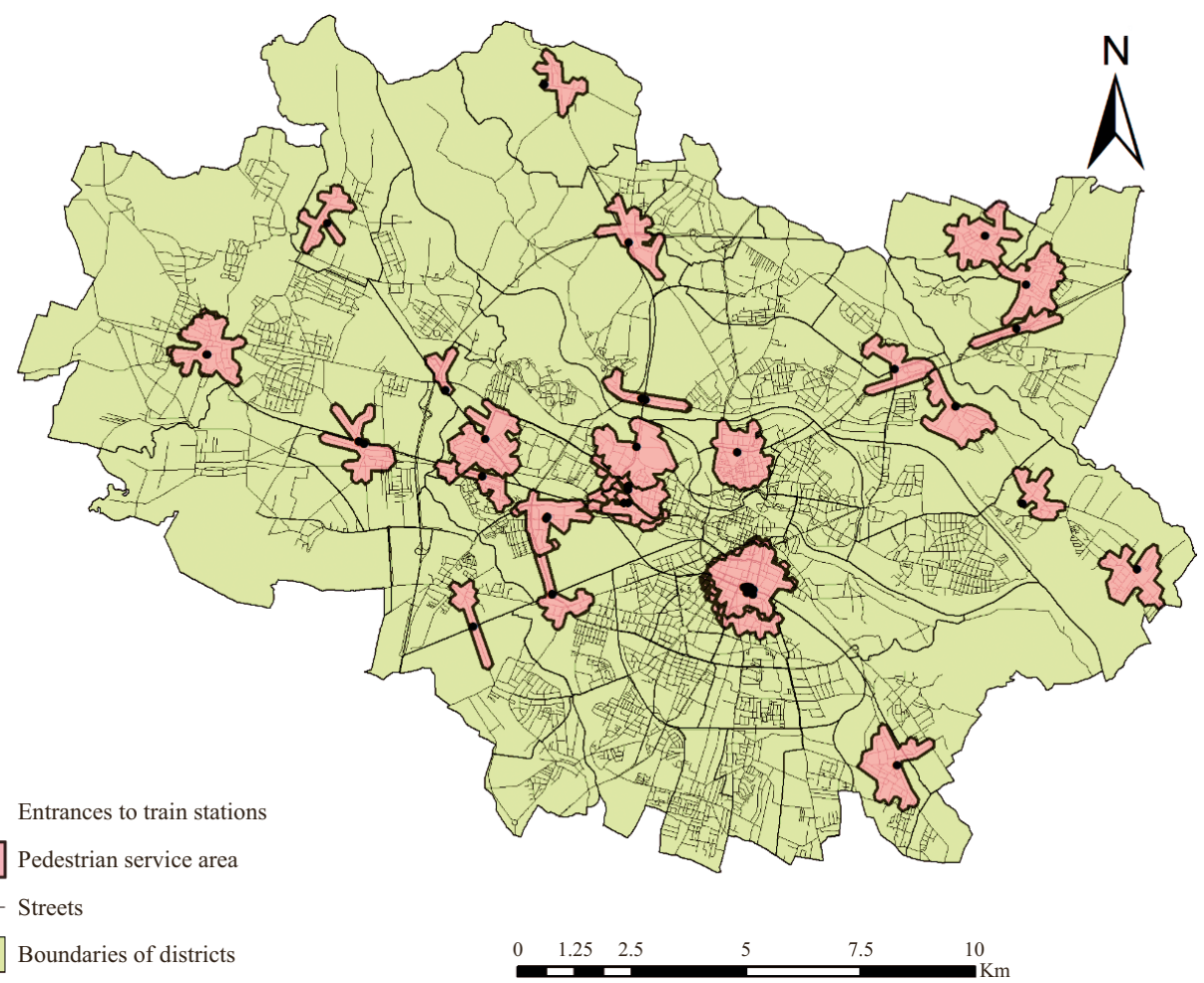

Fig. 1. Service area of railway stations and stops in Wrocław

As each station can have a different number of entrances, all overlapping areas were merged to avoid double accounting. Due to the density of the network on which pedestrians can move, the areas for individual stations and stations vary in both shape and surface.

Table 2 shows the areas of use zones for potential pedestrian traffic for each analyzed railway station and stop.

Table 2. Service area and number of buildings within $1 \mathrm{~km}$ distance from railway stations and stops in Wrocław

\begin{tabular}{||c|c|c|c|}
\hline \hline No. & Name of railway station/stop & Area $\left[\mathrm{m}^{2}\right]$ & Number of buildings \\
\hline \hline 1. & Wrocław Brochów & 1451875 & 1392 \\
\hline 2. & Wrocław Główny & 2898295 & 3392 \\
\hline 3. & Wrocław Grabiszyn & 786917 & 751 \\
\hline 4. & Wrocław Kowale & 1205000 & 1022 \\
\hline
\end{tabular}


Table 2. cont.

\begin{tabular}{|c|c|c|c|}
\hline 5. & Wrocław Kuźniki & 1710938 & 1923 \\
\hline 6. & Wrocław Leśnica & 1524505 & 1359 \\
\hline 7. & Wrocław Mikołajów & 2088970 & 1427 \\
\hline 8. & Wrocław Muchobór & 1158675 & 864 \\
\hline 9. & Wrocław Nadodrze & 1465000 & 1631 \\
\hline 10. & Wrocław Nowy Dwór & 948125 & 1430 \\
\hline 11. & Wrocław Osobowice & 1115938 & 526 \\
\hline 12. & Wrocław Pawłowice & 1324375 & 1438 \\
\hline 13. & Wrocław Popowowice & 1710313 & 1855 \\
\hline 14. & Wrocław Pracze & 775938 & 521 \\
\hline 15. & Wrocław Psie Pole & 649688 & 359 \\
\hline 16. & Wrocław Różanka & 541341 & 291 \\
\hline 17. & Wrocław Sołtysowice & 913750 & 493 \\
\hline 18. & Wrocław Stadion & 359063 & 273 \\
\hline 19. & Wrocław Swojczyce & 670313 & 481 \\
\hline 20. & Wrocław Świniary & 671875 & 695 \\
\hline 21. & Wrocław Wojnów & 1224375 & 1567 \\
\hline 22. & Wrocław Zachodni & 588438 & 526 \\
\hline 23. & Wrocław Zakrzów & 1393125 & 2131 \\
\hline 24. & Wrocław Żerniki & 1178354 & 644 \\
\hline
\end{tabular}

In the context of TOD evaluation, it is also not only important to assess the area within an acceptable from each station but also assume potential importance of each station from the point of view of the number of users. For that purpose, the number of buildings in each zone was calculated. The spatial distribution of the number of buildings is presented in Figure 2. 


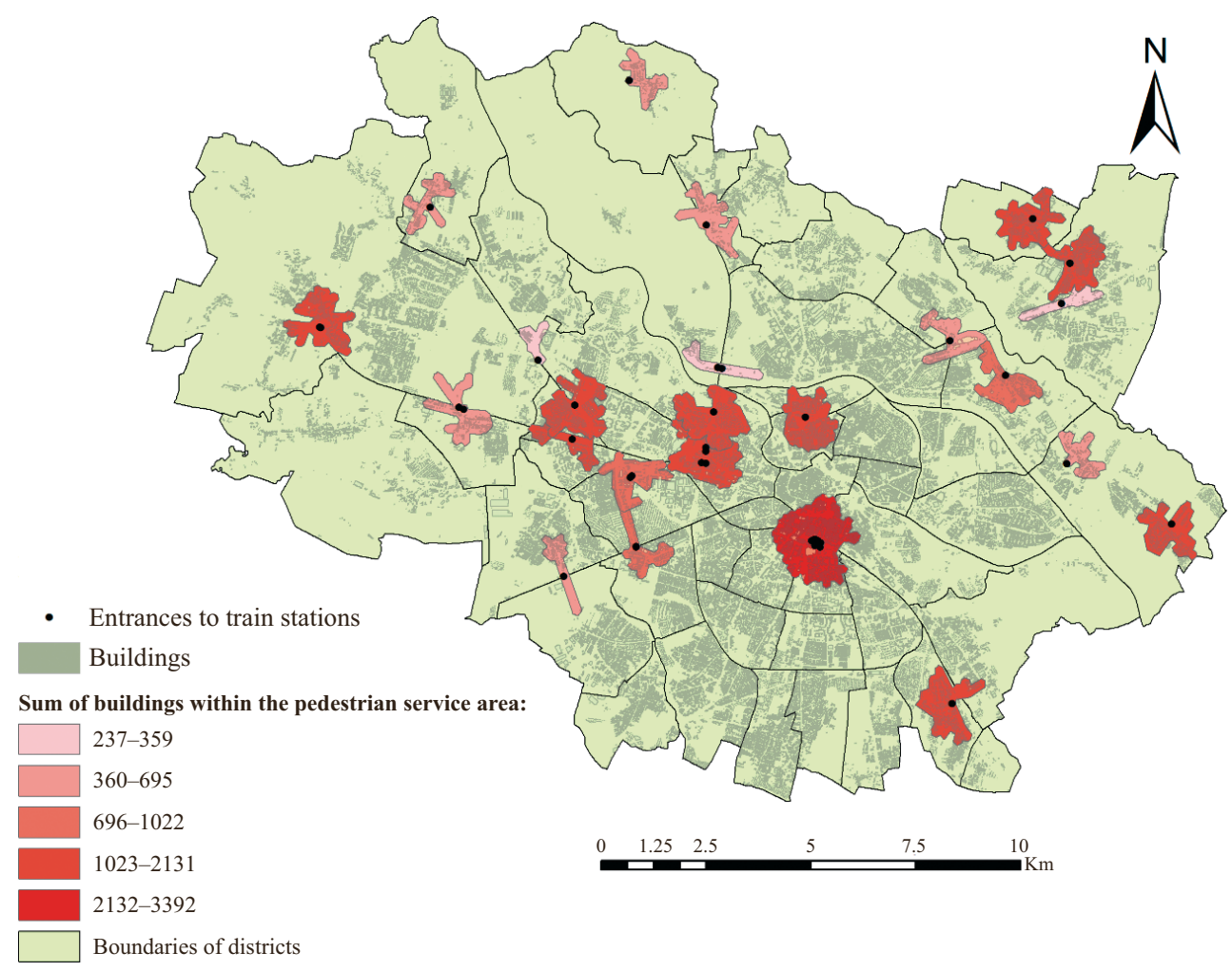

Fig. 2. Number of buildings located within service area of railway stations and stops in Wrocław

The number of building within $1 \mathrm{~km}$ distance from railway stations and stops in Wrocław is included in Table 2. As can be seen, the railway stations and stops with the largest areas offering acceptable access for citizens are Wrocław Główny (approx. $2.8 \mathrm{~km}^{2}$ ), Wrocław Mikołajów (approx. $2 \mathrm{~km}^{2}$ ), and Wrocław Popowice and Wrocław Zakrzów, whose zone sizes are very similar (approx. $1.7 \mathrm{~km}^{2}$ ). Zones of potentially highest number of users (based on the assumption of the highest number of buildings in their area), are located mainly in the city center. These are the service zones for the Wrocław Główny (3,392 buildings), Wrocław Zakrzów (2,131 buildings), and Wrocław Kuźniki (1,923 buildings).

\section{Conclusions}

The assessment of the accessibility of railway stations and stops for pedestrians shows that the service area is not only a result of the number of stations (perhaps the main and intuitive factor), but also strongly depends on the number of entrances to railway stations and stations. This is particularly discernible in Figure 1, where there 
are few visible zones before merging them. The two stations with the largest service zone (Wrocław Główny and Wrocław Mikołajów) have several entrances accessible from different parts of the city. This allows for the convenient use of the station, without taking a detour to get inside. Wrocław Mikołajów station can be an example of a station with very well-located entrance in this regard. This station allows for easy access from the side of Stacyjna Street, from the side of the Magnolia shopping center, which is visited by a large number of people daily, and the entrances on both sides of Legnicka Street. The example of Wrocław Nadodrze is also worth noting. This station is located in a densely developed area but it has only one entrance, located from the side of Staszica Square. This has a direct impact on the shape of the service zone, making the northern part of the zone smaller due to the distance of the point where it is possible to cross railways. A potential future tunnel connecting Wrocław Nadodrze with Dębickiego Street would increase the size of the potential number of citizens living within an acceptable distance of the station.

There are two main limitations to the study that should be highlighted. A major limitation is a lack of available data about the number of people living at exact addresses or even the number of apartments. The availability of such data would allow the improvement of the precision of the obtained results. Based on open access datasets, it was decided to estimate the potential number of probable users of urban trains by the number of buildings within a given service area. A second limitation is connected with the assumption of acceptable distance. Based on the literature review, a $1 \mathrm{~km}$ range was used during the analyses, however, local conditions can be different. While applying such an approach for real case study analysis for urban management decisions, it could be considered necessary to undertake local studies on the acceptable distance from home to public transport stops in order to take into account local social factors.

The assessment proposed in this study has an applicable character and presents how decision makers at a local level can incorporate spatial analysis for more efficient city management. The presented approach has higher precision than visualizations which are commonly used in public spaces to show accessibility to a specific point in a city. Below, an example of the visualization of a 5-minute walk area from a selected point in London is presented (Fig. 3).

The obtained results not only show which areas can be regarded as accessible in the current situation, but may also be a useful insight for decisions on further transportation network development to make important points of public transport more convenient. In that sense, the study constitutes an approach to support better decision making for sustainable development [42,43], which is an important tool in public transport management $[44,45]$. Such activity is in line with local policies in many cities aiming to increase the role of public transport in urban mobility $[46,47]$ and as a side effect also increase the value of real estate [48, 49]. The proposed research concept also corresponds with other studies conducted in Polish conditions on different transportation modes and their relation to sustainable cities [50-55]. 


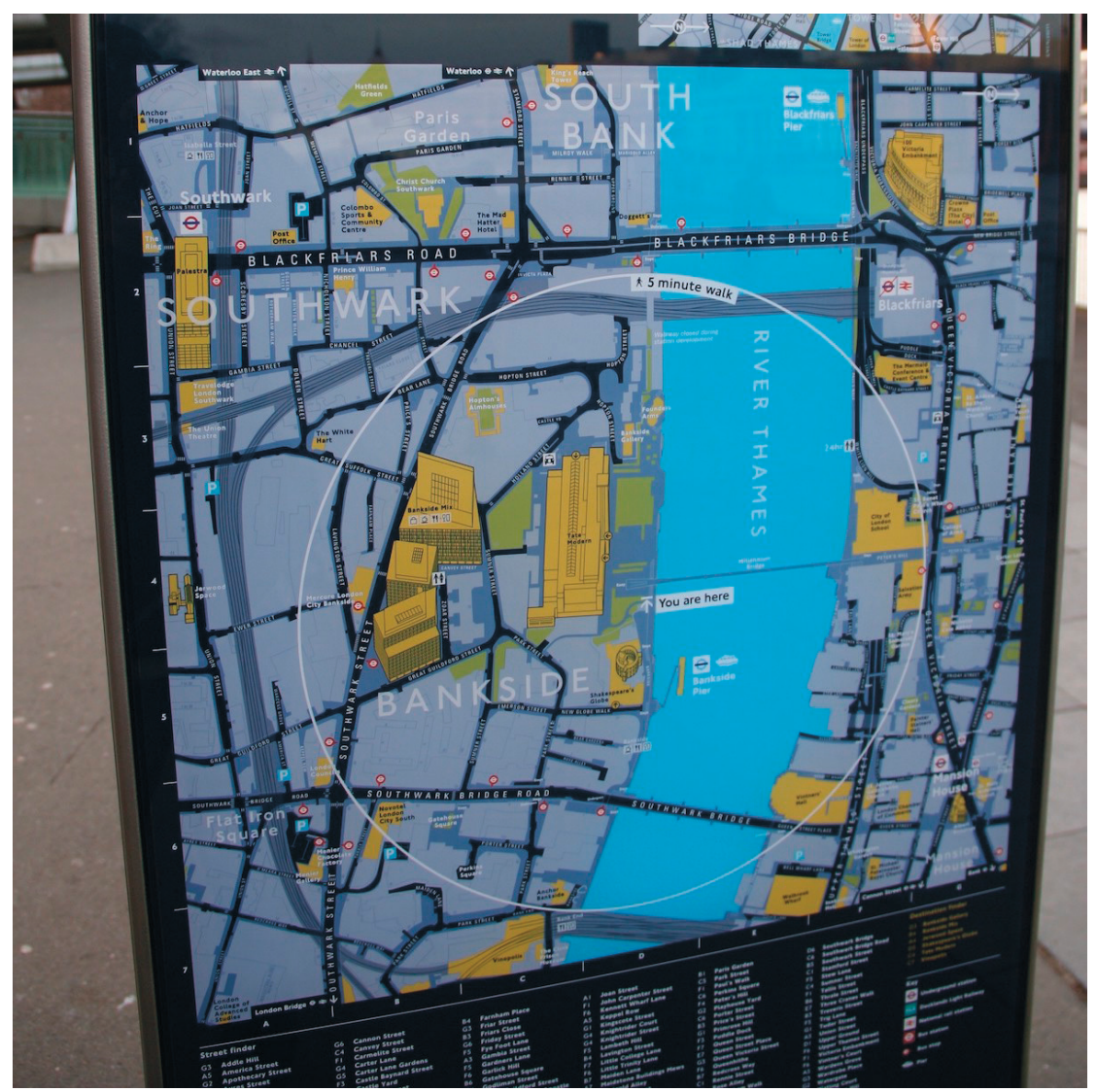

Fig. 3. City map in public space - London

Source: https://medium.com/@Urbica.co/hello-galton-e6e07a7164b7

\section{References}

[1] Zięba Z., Dąbrowska J., Marschalko M., Pinto J., Mrówczyńska M., Leśniak A., Petrovski A., Kazak J.K.: Built environment challenges due to climate change. IOP Conference Series: Earth and Environmental Science, vol. 609, 2020, art. no. 012061.

[2] United Nations General Assembly: Transforming our World: The 2030 agenda for sustainable development. 2015. https://sustainabledevelopment.un.org/ content/documents/21252030\%20Agenda\%20for\%20Sustainable\%20Development\%20web.pdf [access: 25.03.2021].

[3] Świąder M., Szewrański S., Kazak J.: Poverty Risk Index as A New Methodology for Social Inequality Distribution Assessment. IOP Conference Series: Materials Science and Engineering, vol. 245, 2017, art. no. 072021. 
[4] Kisiała W., Rącka I.: Spatial and Statistical Analysis of Urban Poverty for Sustainable City Development. Sustainability, vol. 13(2), 2021, art. no. 858. https://doi. org/10.3390/su13020858.

[5] Hachoł J., Bondar-Nowakowska E.: Aquatic plants-based risk model for assessment of ecological safety of rivers. Human and Ecological Risk Assessment, vol. 22, 2016, pp. 1065-1077. https://doi.org/10.1080/10807039.2015.1138088.

[6] Migdał P., Roman A., Popiela-Pleban E., Kowalska-Góralska M., Opaliński S.: The impact of selected pesticides on honey bees. Polish Journal of Environmental Studies, vol. 27, 2018, pp. 787-792. https://doi.org/10.15244/ pjoes/74154.

[7] Santana M.V.E., Cornejo P.K., Rodríguez-Roda I., Buttiglieri G., Corominas L.: Holistic life cycle assessment of water reuse in a tourist-based community. Journal of Cleaner Production, vol. 233, 2019, pp. 743-752. https://doi.org/10.1016/j.jclepro.2019.05.290.

[8] Ziemiańska M., Kalbarczyk R., Sobota M.: Replacement planting in the light of the polish law - an effective or token tool of environmental compensation? Acta Scientiarum Polonorum Administratio Locorum, vol. 18, no. 3, 2019, pp. 323-333. https://doi.org/10.31648/aspal.4188.

[9] Kwartnik-Pruc A., Trembecka A.: Public Green Space Policy Implementation: A Case Study of Krakow, Poland. Sustainability, vol. 13, 2021, art. no. 538. https://doi.org/10.3390/su13020538.

[10] Mrówczyńska M., Skiba M., Bazan-Krzywoszańska A., Bazuń D., Kwiatkowski M.: Social and Infrastructural Conditioning of Lowering Energy Costs and Improving the Energy Efficiency of Buildings in the Context of the Local Energy Policy. Energies, vol. 11, 2018, art. no. 2302. https://doi.org/10.3390/en11092302.

[11] Hernik J., Noszczyk T., Rutkowska A.: Towards a better understanding of the variables that influence renewable energy sources in eastern Poland. Journal of Cleaner Production, vol. 241, 2019, art. no. 118075. https://doi.org/10.1016/ J.JCLEPRO.2019.118075.

[12] Mrówczyńska M., Skiba M., Sztubecka M., Bazan-Krzywoszańska A., Kazak J.K., Gajownik P.: Scenarios as a tool supporting decisions in urban energy policy: The analysis using fuzzy logic, multi-criteria analysis and GIS tools. Renewable and Sustainable Energy Reviews, vol. 137, 2021, art. no. 110598. https://doi.org/10.1016/j.rser.2020.110598.

[13] Przybyłowicz A.: The legal position of persons dependent on long-term care in the Republic of Poland. [in:] Becker U., Reinhard H.-J. (eds.), Long-Term Care in Europe: A Juridical Approach, Springer International Publishing, 2018, pp. 381-413.

[14] Kurtyka-Marcak I., Hełdak M., Przybyła K.: The actual demand for the elimination of architectural barriers among senior citizens in Poland. International Journal of Environmental Research and Public Health, vol. 16(4), 2019, art. no. 2601. https://doi.org/10.3390/ijerph16142601. 
[15] Przybyła K., Hełdak M., Kurtyka-Marcak I.: Demand for a housing offer addressed to senior citizens in Poland. International Journal of Environmental Research and Public Health, vol. 16(4), 2019, art. no. 4573. https://doi. org/10.3390/ijerph16224573.

[16] Furmankiewicz M., Campbell A.: From Single-Use Community Facilities Support to Integrated Sustainable Development. The Aims of Inter-Municipal Cooperation in Poland, 1990-2018. Sustainability, vol. 11, 2019, art. no. 5890. https://doi.org/10.3390/su11215890.

[17] Furmankiewicz M., Hewitt R.J., Janc K., Kazak J.K.: Europeanisation of energy policy and area-based partnerships: Regional diversity of interest in renewable energy sources in local development strategies in Poland. IOP Conference Series: Earth and Environmental Science, vol. 609, 2020, art. no. 012033. https://doi. org/10.1088/1755-1315/609/1/012033.

[18] Przybyła K., Kulczyk-Dynowska A., Kachniarz M.: Quality of Life in the Regional Capitals of Poland. Journal of Economic Issues, vol. 48, 2014, pp. 181-196. https://doi.org/10.2753/JEI0021-3624480109.

[19] Szewrański S., Kazak J.K.: Socio-environmental vulnerability assessment for sustainable management. Sustainability, vol. 12(19), 2020, art. no. 7906. https://doi. org/10.3390/SU12197906.

[20] Partnership on Sustainable Low Carbon Transport (SLoCaT): Contribution of Transport Commitments to Global Goals on Sustainable Development: 2015 Transport Commitments Report. 2015. http://www.slocat.net/wp-content/uploads/ legacy/u13/2015_transport_commitments_report_2.pdf [access: 25.03.2021].

[21] Craven N., Philippe M.-L.: Railways as the Backbone of Environmentally Sustainable Transport and their Contribution to the Sustainable Development Goals (SDGs). 2017. https://www.uncrd.or.jp/content/documents/4952Background\%20 Paper\%20(2)-EST\%20Plenary\%20Session\%2011.pdf [access: 25.03.2021].

[22] United Nations: The sustainable development goals report 2019. 2019. https://unstats.un.org/sdgs/report/2019/The-Sustainable-Development-Goals-Report-2019.pdf [access: 25.03.2021].

[23] Heinrichs D., Bernet J.S.: Public Transport and Accessibility in Informal Settlements: Aerial Cable Cars in Medellín, Colombia. Transportation Research Procedia, vol. 4, 2014, pp. 55-67. https://doi.org/10.1016/j.trpro.2014.11.005.

[24] Lättman K., Olsson L.E., Friman M.: Development and test of the Perceived Accessibility Scale (PAC) in public transport. Journal of Transport Geography, vol. 54, 2016, pp. 257-263. https://doi.org/10.1016/j.jtrangeo.2016.06.015.

[25] Yatskiv I., Budilovich E., Gromule V.: Accessibility to Riga Public Transport Services for Transit Passengers. Procedia Engineering, vol. 187, 2017, pp. 82-88.

[26] Eriksson L., Garvill J., Nordlund A.M.: Acceptability of single and combined transport policy measures: The importance of environmental and policy specific beliefs. Transportation Research Part A: Policy and Practice, vol. 42, 2008, pp. 1117-1128. https://doi.org/10.1016/j.tra.2008.03.006. 
[27] Milakis D., van Wee B.: For me it is always like half an hour: Exploring the acceptable travel time concept in the US and European contexts. Transport Policy, vol. 64, 2018, pp. 113-122. https://doi.org/10.1016/j.tranpol.2018.02.001.

[28] Islam Sarker R.: *A101 Surveying acceptable walking distance to different modes of local public transport in Munich area ID. Journal of Transport \& Health, vol. 2, issue 2, Supplement, 2015, pp. S57-S58. https://doi.org/10.1016/j.jth.2015.04.589.

[29] Wakenshaw G., Bunn N.: How far do people walk? PTRC Transport, London 2015. https://www.wyg.com/uploads/files/news/WYG_how-far-do-peoplewalk.pdf [access: 20.06.2020].

[30] Yang R., Yan H., Xiong W., Liu T.: The Study of Pedestrian Accessibility to Rail Transit Stations based on KLP Model. Procedia - Social and Behavioral Sciences, vol. 96, 2013, pp. 714-722. https://doi.org/10.1016/j.sbspro.2013.08.082.

[31] Connor D.O., Harrison O.: Rail Catchment Analysis in the Greater Dublin Area. 2012. https://arrow.tudublin.ie/cgi/viewcontent.cgi?article=1013\&context=beschspcon [access: 25.03.2021].

[32] Pongprasert P., Kubota H.: TOD residents' attitudes toward walking to transit station: a case study of transit-oriented developments (TODs) in Bangkok, Thailand. Journal of Modern Transportation, vol. 27, 2019, pp. 39-51. https://doi. org/10.1007/s40534-018-0170-1.

[33] Stead D., Schremmer C., Schmitt P.: Transit-oriented development and sustainable urban planning. 2016. https://www.nordregio.org/wp-content/ uploads/2018/09/CASUAL-PB-2.pdf [access: 25.03.2021].

[34] Kazak J., Szewranski S., Decewicz P.: Holistic Assessment of Spatial Policies for Sustainable Management: Case Study of Wroclaw Larger Urban Zone (Poland). [in:] Lee D., Dias E., Scholten H.J. (eds.), Geodesign by Integrating Design and Geospatial Sciences, Springer, Cham, 2014, pp. 71-85.

[35] Stacherzak A., Hełdak M., Raszka B.: Planning documents and sustainable development of a commune in Poland. [in:] Brebbia C.A., Chon T.-S. (eds.), Environmental Impact, WIT Transactions on Ecology and the Environment, vol. 162, WIT Press, 2012, pp. 23-34.

[36] Forys I., Cymerman J.: Spatial Analysis of the Sustainable Development Level in Polish Voivodship: Dynamic Approach. IOP Conference Series: Materials Science and Engineering, vol. 471, 2019, art. no. 102017. https://doi.org/10.1088/1757899X/471/10/102017.

[37] Krajewski P., Solecka I.: Management System of Urban Landscape in Poland on the Example of Wroclaw in the Context of European Landscape Convention Implementation. IOP Conference Series: Materials Science and Engineering, vol. 471, 2019, art. no. 112035. https://doi.org/10.1088/1757-899X/471/11/112035.

[38] Belčáková I., Świąder M., Bartyna-Zielińska M.: The Green Infrastructure in Cities as A Tool for Climate Change Adaptation and Mitigation: Slovakian and Polish Experiences. Atmosphere (Basel), vol. 10, 2019, art. no. 552. https://doi. org/10.3390/atmos10090552. 
[39] Tymiński T.: Wielkogabarytowy model laboratoryjny Wrocławskiego Węzła Wodnego [Large-Size Laboratory Model of Wrocław Hydrotechnical System]. Nauka Przyroda Technologie. Uniwersytet Przyrodniczy w Poznaniu, t. 5, nr 6, 2011, pp. 1-11. http://www.npt.up-poznan.net/pub/art_5_110.pdf [access: 25.03.2021].

[40] Kamińska J.A.: The use of random forests in modelling short-term air pollution effects based on traffic and meteorological conditions: A case study in Wroctaw. Journal of Environmental Management, vol. 217, 2018, pp. 164-174. https://doi. org/10.1016/J.JENVMAN.2018.03.094.

[41] Browning R.C., Baker E.A., Herron J.A., Kram R.: Effects of obesity and sex on the energetic cost and preferred speed of walking. Journal of Applied Physiology, vol. 100, 2006, pp. 390-398. https://doi.org/10.1152/japplphysiol.00767.2005.

[42] García Castro D., De Elizagarate Gutierrez V., Kazak J., Szewranski S., Kaczmarek I., Wang T.: Nuevos desafíos para el perfeccionamiento de los procesos de participación ciudadana en la gestión urbana. Retos para la innovación social [New challenges in the improvement of the citizen participation processes of the urban management. Social innovation challenges]. Cuadernos de Gestión, vol. 20, no. 1, 2020, pp. 41-64. https://doi.org/10.5295/cdg.170751dg.

[43] Chruscinski J., Kazak J.K., Tokarczyk-Dorociak K., Szewranski S., Swiader M.: How to Support Better Decision Making for Sustainable Development? IOP Conference Series: Materials Science and Engineering, vol. 471, issue 11, 2019, art. no. 112008. https://doi.org/10.1088/1757-899X/471/11/112008.

[44] Kazak J., Chalfen M., Kamińska J., Szewrański S., Świąder M.: Geo-Dynamic Decision Support System for Urban Traffic Management. [in:] Ivan I., Horák J., Inspektor T. (eds.), Dynamics in GIscience, Lecture Notes in Geoinformation and Cartography, Springer, Cham 2018, pp. 195-207.

[45] Kazak J.K., Castro D.G., Swiader M., Szewranski S.: Decision Support System in Public Transport Planning for Promoting Urban Adaptation to Climate Change. IOP Conference Series: Materials Science and Engineering, vol. 471, issue 11, 2019, art. no. 112007. https://doi.org/10.1088/1757-899X/471/11/112007.

[46] Brzóska A., Swianiewicz P.: Elastyczność popytu na lokalny transport zbiorowy w polskich miastach [Demand elasticity of local public transport in Polish cities]. Studia Regionalne i Lokalne, nr 2(80), 2020, pp. 67-91. https://doi. org/10.7366/1509499528004.

[47] Swianiewicz P., Brzóska A.: Demand elasticity for local public transport in Polish cities: Do local policies matter? Transylvanian Review of Administrative Sciences, vol. 16(61), 2020, pp. 125-142. https://doi.org/10.24193/tras.61E.7.

[48] Kazak J.K., Simeunović N., Hendricks A.: Hidden Public Value Identification of Real Estate Management Decisions. Real Estate Management and Valuation, vol. 27, issue 4, 2019, pp. 96-104. https://doi.org/10.2478/remav-2019-0039.

[49] Bieda A.: Urban renewal and the value of real properties. Studia Regionalne i Lokalne, nr 3(69), 2017, pp. 5-28. https://doi.org/10.7366/1509499536901. 
[50] Szopińska K.: Sustainable Urban Transport and the Level of Road Noise - a Case Study of the City of Bydgoszcz. Geomatics and Environmental Engineering, vol. 13, no. 4, 2019, pp. 93-107. https://doi.org/10.7494/geom.2019.13.4.93.

[51] Jaszczak A., Morawiak A., Żukowska J.: Cycling as a Sustainable Transport Alternative in Polish Cittaslow Towns. Sustainability, vol. 12, 2020, art. no. 5049. https://doi.org/10.3390/su12125049.

[52] Tarkowski M., Puzdrakiewicz K., Jaczewska J., Połom M.: COVID-19 lockdown in Poland - changes in regional and local mobility patterns based on Google Maps data. Prace Komisji Geografii Komunikacji PTG, vol. 23, 2020, pp. 46-55. https://doi.org/10.4467/2543859xpkg.20.007.12105.

[53] Kazak J., Wang T., Szewrański S.: Analysis of land use transformation potential in spatial management. Real Estate Management and Valuation, vol. 23, 2015, pp. 5-14. https://doi.org/10.1515/remav-2015-0001.

[54] Szczepańska A.: Expansion of the Transport System as a Factor Affecting the Real Estate Market, with the Construction of the Olsztyn Ring-Road as an Example. Real Estate Management and Valuation, vol. 27, 2019, pp. 39-52. https://doi. org/10.2478/remav-2019-0034.

[55] Trojanek R., Gluszak M.: Spatial and time effect of subway on property prices. Journal of Housing and the Built Environment, vol. 33, 2018, pp. 359-384. https://doi.org/10.1007/s10901-017-9569-y. 